Canadian University Music Review

Revue de musique des universités canadiennes

\title{
Speeches for Dr. Frankenstein: An Orchestral Approach to Music Synthesis
}

\section{Bruce W. Pennycook}

Numéro 4, 1983

URI : https://id.erudit.org/iderudit/1013903ar

DOI : https://doi.org/10.7202/1013903ar

Aller au sommaire du numéro

Éditeur(s)

Canadian University Music Society / Société de musique des universités canadiennes

ISSN

0710-0353 (imprimé)

2291-2436 (numérique)

Découvrir la revue

Citer cet article

Pennycook, B. W. (1983). Speeches for Dr. Frankenstein: An Orchestral Approach to Music Synthesis. Canadian University Music Review / Revue de musique des universités canadiennes, (4), 196-203.

https://doi.org/10.7202/1013903ar

(c) Canadian University Music Society / Société de musique des universités canadiennes, 1983
Ce document est protégé par la loi sur le droit d'auteur. L'utilisation des services d'Érudit (y compris la reproduction) est assujettie à sa politique d'utilisation que vous pouvez consulter en ligne.

https://apropos.erudit.org/fr/usagers/politique-dutilisation/ 


\title{
SPEECHES FOR DR. FRANKENSTEIN: AN ORCHESTRAL APPROACH TO MUSIC SYNTHESIS
}

\author{
Bruce W. Pennycook
}

Speeches for Dr. Frankenstein ${ }^{1}$ was commissioned through the Canada Council for the Arts in 1980 by Dexter Morrill, Director of the Colgate Computer Music Center, and Neva Pilgrim, soprano soloist and a leading interpreter of voice and tape music. The texts for these songs are stanzas I, IV, VII, and X of the tenstanza poem, Speeches for Dr. Frankenstein, by the well-known Canadian poet and author Margaret Atwood. This poem was published in the collection, The Animals In That Country, in 1968 by Oxford University Press. I wish to express my gratitude to Margaret Atwood for her permission to use these outstanding texts. The tape accompaniment was digitally synthesized at the Center for Computer Research in Music and Acoustics at Stanford University. Final editing and performance tape preparation was completed at Destiny Sound Studios in Kingston, Ontario.

The commissioners had requested a work of approximately fifteen minutes duration that would complement the other works on a programme of pieces for soprano and computer-generated tape music which has toured extensively in the United States and Europe. The soloist, Neva Pilgrim, had extensive experience in opera and other dramatic forms, which suggested that a dramatic song cycle would be most suitable. Actually, I had read the Atwood poems many years earlier and had tucked them away as a future project. The setting of all ten stanzas, however, would have produced a work closer to one hour in length and have required a somewhat different approach to both the vocal writing and the synthesis.

The four stanzas that I have extracted outline the basic progression of dramatic events in the poem: preparation for the 
act, the creation, reflection on the deed, and separation of the creator from the monster. The poem is not a direct rewrite of the Shelly novel, although Atwood's text certainly evokes some potent images from the original. Rather, it is a unique and in some ways more complex narrative on one of man's timeless conflicts: the creator versus the created.

The musical style of Speeches for Dr. Frankenstein is essentially that of dramatic song set in a relatively conventional rhythmic framework. The flow of the poetic images and the pace and sound of the language have guided the musical shapes throughout. Some images have been used on a simple one-toone basis. In stanza IV, "Now I shall ornament you," I have used the words, "ornament" and, later, "Baroque," to guide the textural quality and melismatic detail. An example of a direct acoustical relationship occurs at the end of this same stanza. The synthesized "voices" match the pitch and sound of the text-"your eyes."

Less direct relationships also exist which function more on musical rather than illustrative levels. The opening motive, "I the performer ..." (Ex. 1a) occurs in various forms throughout the cycle as a generative melodic structure but occurs in exact form only once with the text, "I am a vestige..." (Ex. 1b) in stanza VII. The narrator has traversed the entire path-from omnipotence to total incapacity.
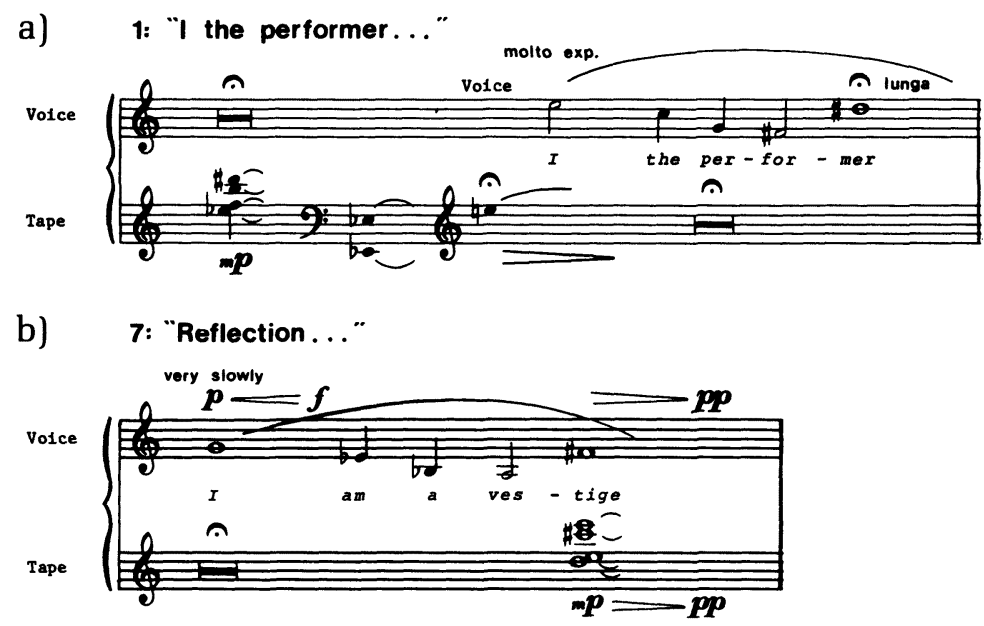

Pennycook: Speeches for Dr. Frankenstein (1980). 
There exist many more links between text and musical activity in this work, inspired by the dramatic power and florid imagery of Atwood's text. I have constructed what I hope is a musical setting that not only complements but enlarges the sense of conflict in the poem. The choice of computer-generated accompaniment rather than conventional orchestral forces should invoke images consistent with the growing presence of mancreated intelligent machines in our society.

The synthesis device used for this work is a large and very powerful special purpose audio signal generating and processing computer. It was constructed in $\mathbf{1 9 7 8}$ for the Center for Computer Research in Music and Acoustics at Stanford University by Systems Concepts of Oakland, California. This device is interfaced to a general-purpose computer system which transmits control statements, instructions, and music performance data typed in at a graphic display terminal by the composer. At the time this work was realized, there were no music performance peripheral devices such as keyboards, joysticks, or even knobs. This meant that all acoustical and musical activity had to be described explicitly as alpha-numeric data and signal generating algorithms.

The principal and critical difference between this system and more conventional software-based music synthesis systems, such as the Computer Audio Research Laboratories at the University of California at San Diego or the Experimental Music Studio at the Massachusetts Institute of Technology, is that the time interval between submission of the data and audition of the computed sound pressure waves has been reduced from intolerable lengths to a few minutes. Although many commercially available digital synthesizers produce an instantaneous response when a key is struck or a routine invoked, these organlike units have a relatively limited synthesis capacity. The Systems Concepts device, however, combines programmability, great speed, and sufficient power to generate many computationally complex voices, plus controllable four-channel distribution and digital reverberation, all in "real-time." The net result was that I was able to generate and audition each section of the work many times, permitting extensive revisions and improvements. The entire tape accompaniment was typed-in, synthesized, revised, and assembled into each piece in only fourteen days!

My approach to the tape portion of Speeches for Dr. 
Frankenstein grew out of a previous knowledge of several elaborate audio signal generating algorithms and a relatively clear understanding of the capacities of the synthesis environment at Stanford. Historically, composers and scientists have referred to these sound generating algorithms as "instruments." That is, each particular synthesis routine exhibits certain acoustical properties which may be "bell-like," "drum-like," "explosionlike," "voice-like," etc. For this composition an "orchestra"of computer instruments was assembled from an instrument library available to all users at Stanford. Some of these were then modified to better serve my purposes for this composition. Each instrument algorithm, which is in fact a special type of computer program, can be used for as many voices of sound as needed thus serving as a template for the actual sound generating process. The opening passage of this piece uses up to ten iterations of a very complex routine which has acoustical properties well-suited to string-like sustained tones (see Schottstaedt 1977). This is not to suggest that the sounds in this work are meant to mimic directly real instruments and voices, but that their properties and subsequent compositional utilization offer parallels to musical sounds produced by orchestral instruments.

Many electronic and computer compositions strive to place new acoustical material into unique and startling relief. In contrast, my goals were focused on achieving a more or less familiar orchestral dimension and sonority which would serve to support the intense, dramatic vocal writing by providing the soprano with a rich, complex and acoustically enveloping sound.

I have engaged several techniques to achieve this while maintaining an elastic, rhythmically supple musical style. These operate on three levels of the compositional process: notation in score, computation of the note data, and synthesis methods.

The score, which must serve as a rhythmic guide for the soloist, contains a mixture of regularly metered material and freely notated non-metrical passages. The metered material is frequently interrupted, augmented, or compressed. These transformations are notated in "synch" with the vocal line. The bell sounds in the following passage from the second song act as the timing guide for the soloist against the very busy irregular activity of the other parts (Ex. 2): 
4. "Now I shall ornament you" (excerpt)
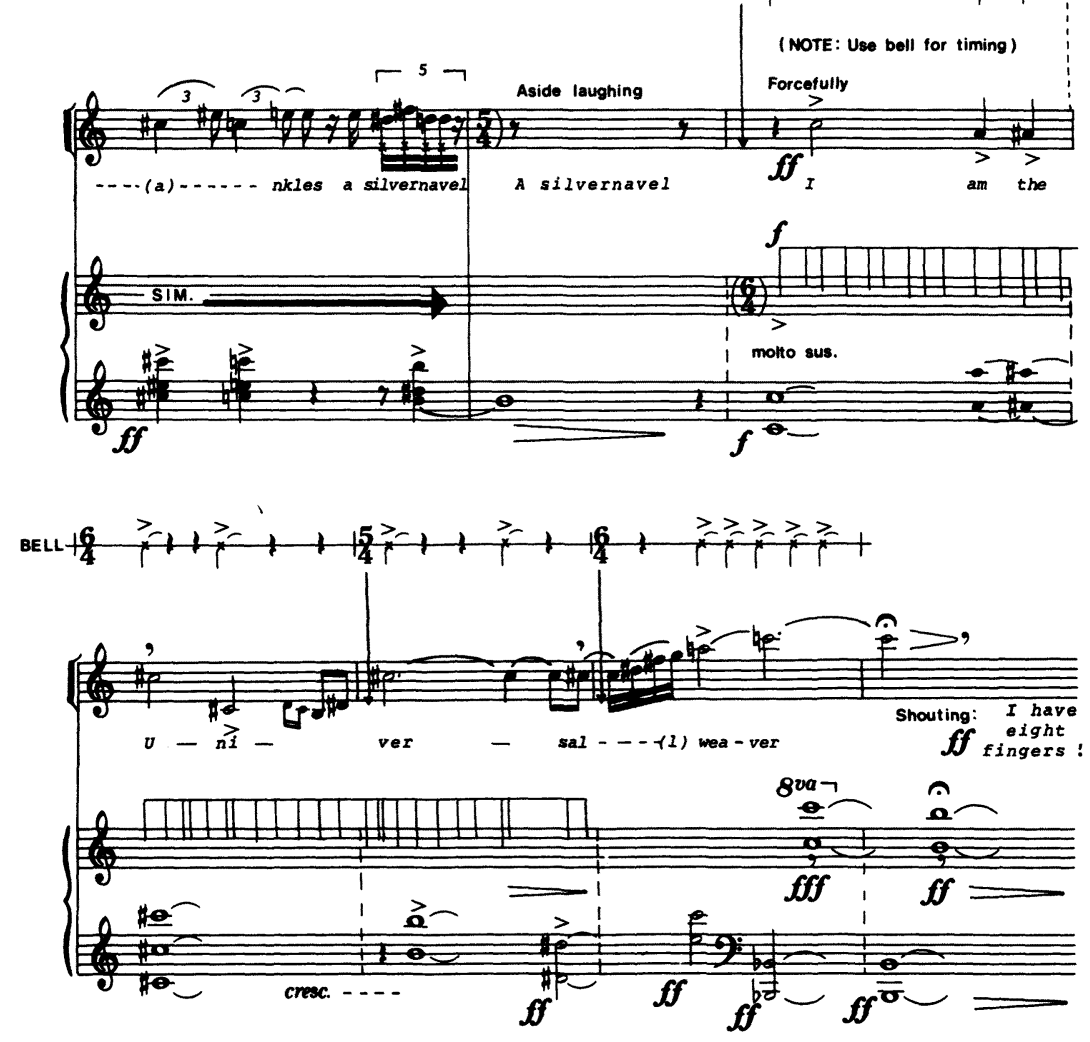

Pennycook: Speeches for Dr. Frankenstein (1980).

Example 2

The controlling factor in these designs was the pace of the delivery of each line of the text. This approach resulted in a series of similar but not identical rhythmic passages connected by pauses or brief tape interludes of varying lengths. All of these details have been carefully notated in score to minimize performance problems.

An often irritating aspect of evenly-pulsed electronically 
produced music is that the duration values are too uniform, resulting in mechanical "news-bulletin" style music. The music data encoding program, SCORE, developed by Leland Smith of Stanford (see Smith 1972) permits the composer to add a variable percentage of random deviation to the absolute note durations and to adjust the tempo markings independently in each voice. The tempo variations may be expressed as a constant value over some duration or as linearly changing values producing ritardandos and accelerandos. Though the application of small random deviations to duration values is a rather coarse and unscientific means of imbedding human performance-like imprecision, the resulting note values-all slightly differentseem much more musical and life-like than precise, invariably symmetrical durations. Of course, the subtle, finely controlled variations of duration and pace that an experienced performer intuitively imposes, are of a much more complex nature. A recent study has shown that keyboard players, for example, stretch and compress notationally equivalent note values according to dynamic shading, position in the phrase, surrounding musical activity, and many other factors (see Lamb 1978). The utilization of more sophisticated context-dependent durational control algorithms awaits more statistical information from which some general properties can be extracted. Nevertheless, the mechanisms provided by SCORE and other note-data generating programs produce reasonably convincing rhythmic perturbations.

The third technique I have engaged is more complex, being a combination of three related signal-manipulation processes. Many of the "instruments" in this composition function as voice aggregates to produce a chorus effect. This effect, used extensively in digital compositions by Schottstaedt at Stanford, is best illustrated by comparing the sound of one or two instruments or voices to the unison sound of a large number of like voices such as a violin section. The slight variances in tuning and vibrato by each member of the section adds a characteristic depth and resonance. Similarly, the simulation of this effect enhances otherwise rather flat, electronic sounding tones. The synthesized voices are then blended together across the stereo image to produce a sense of spatial distribution of the "choir." (One of the best sellers of the rock electronics market is the choralizor, a device added between the guitar or piano and the amplifier, which simulates the choral affect through minute displacements of the entry timings, relative pitches, and vibrato depths of each component voice.) 
In conjunction with the chorus effect, I have caused the notes of certain passages to overlap each other much the way tones blend when the sustain pedal is held down on the piano or when music is performed in highly reverberant spaces. These two effects, choralizing and overlap, are further compounded by the use of long reverberation times. The net result is a dense, rhythmically ambiguous acoustical space.

Another aspect of my compositional process more closely resembles conventional orchestration. The composer working in the computer environment must understand the sound generating components of the digital orchestra at every level of the compositional/synthesis process. A computer instrument has no prior knowledge of other repertoire or similar orchestral passages and therefore must be provided with a complete set of data for every note and phrase. Alternatively, the instrument can be provided with a set of rules from which it can deduce correct data for a given musical circumstance. This is perhaps the most intriguing aspect of the whole process. It is possible to have decision-making programs that are more than just black boxes into which the composer stuffs pitches, rhythms, volumes, etc. These adaptive computer instruments are, in fact, programs which scan current incoming musical data and compare it with previous events or internal sets of rules about timbral characteristics, amplitude contours, and other relevant factors. From these decisions the actual synthesis data (a stream of numbers) is produced without the composer having to deal with all of the details for each and every note. This is a logical progression in computer music research and practice. After all, the composer of a woodwind quintet should not be expected to cope with reed-making guides or French Horn bell-shape analyses.

These techniques I have just described are only possible within a programmable music synthesis environment. Many composers of computer music are actively investigating various forms of synthesis automation and computer-aided composition (see Roads 1980). Recent entries into the commercial digital synthesizer market exhibit similar sophisticated performance control mechanisms. There is no doubt that as the home computer music-making market grows, the availability of sophisticated music software and synthesis hardware will flourish.

In Speeches for Dr. Frankenstein I have attempted to produce a tape accompaniment that is life-like and complementary to the soloist-not a mimicry or poor simulation of a live ensemble, 
but an acoustical environment which parallels the dynamic, rhythmic, and timbral variety of live performance. The techniques I have described are, in a real sense, orchestrations of musical ideas for computer synthesis instruments. As we, the composer/scientists, learn more and more about the subtle and infinitely varied nuances of human performance, synthesized music will continue to shed its mechanical, two-dimensional barriers and, hopefully, become an equal partner with conventional instruments and voices. This must not be considered as a threat to violinists, pianists, jazz saxophonists, or contraltos, as only the most commercially minded and musically insensitive would suggest that a computer of any level of sophistication could replace a Horowitz or displace a Perlman.

\section{NOTES}

1. The score of Speeches for Dr. Frankenstein is available from the Canadian Music Centre, 1240 Bay Street, Toronto, Ontario. Recording: Proceedings of the 1981 International Computer Music Conference, North Texas State University, Denton, Texas. Soprano: Billy Bridgeman (Folkways FTS 37475).

\section{REFERENCES}

LAMB, M. R.

1978: "André Tchaikovsky Meets the Computer: A Concert Pianist's Impromptu Encounter with a Musicianship Teaching Aid," International Journal of Man-Machine Studies, X/1, 593-602.

ROADS, C.

1980: "Artificial Intelligence and Music," Computer Music Journal, IV/2, 13-25.

SCHOTTSTAEDT, B.

1977: "The Simulation of Natural Instrument Tones using Frequency Modulation with a Complex Modulating Wave," Computer Music Journal, I/4, 46-50.

SMITH, L.

1972: "SCORE-A Musician's Approach to Computer Music," Journal of the Audio Engineering Society, XX/1, 7-14. 